\title{
Advances in earthquake and tsunami sciences and disaster risk reduction since the 2004 Indian ocean tsunami
}

Kenji Satake

\begin{abstract}
The December 2004 Indian Ocean tsunami was the worst tsunami disaster in the world's history with more than 200,000 casualties. This disaster was attributed to giant size (magnitude $M \sim 9$, source length $>1000 \mathrm{~km}$ ) of the earthquake, lacks of expectation of such an earthquake, tsunami warning system, knowledge and preparedness for tsunamis in the Indian Ocean countries. In the last ten years, seismology and tsunami sciences as well as tsunami disaster risk reduction have significantly developed. Progress in seismology includes implementation of earthquake early warning, real-time estimation of earthquake source parameters and tsunami potential, paleoseismological studies on past earthquakes and tsunamis, studies of probable maximum size, recurrence variability, and long-term forecast of large earthquakes in subduction zones. Progress in tsunami science includes accurate modeling of tsunami source such as contribution of horizontal components or "tsunami earthquakes", development of new types of offshore and deep ocean tsunami observation systems such as GPS buoys or bottom pressure gauges, deployments of DART gauges in the Pacific and other oceans, improvements in tsunami propagation modeling, and real-time inversion or data assimilation for the tsunami warning. These developments have been utilized for tsunami disaster reduction in the forms of tsunami early warning systems, tsunami hazard maps, and probabilistic tsunami hazard assessments. Some of the above scientific developments helped to reveal the source characteristics of the 2011 Tohoku earthquake, which caused devastating tsunami damage in Japan and Fukushima Dai-ichi Nuclear Power Station accident. Toward tsunami disaster risk reduction, interdisciplinary and trans-disciplinary approaches are needed for scientists with other stakeholders.
\end{abstract}

Keywords: Earthquake; Tsunami; Disaster risk reduction; Tsunami warning system; The 2004 Indian Ocean tsunami; The 2011 Tohoku tsunami

\section{Introduction}

On 26 December 2004, five months after the inauguration of the Asia Oceania Geoscience Society (AOGS), the countries around the Indian Ocean suffered from the devastating tsunami. This tsunami, generated by the Sumatra-Andaman earthquake (magnitude $M$ 9.1), was the worst tsunami disaster in the world's written history, and the casualties were not only from the Indian Ocean countries but also extended to European countries because many tourists were spending their Christmas vacations in Asian countries.

Correspondence: satake@eri.u-tokyo.ac.jp

Earthquake Research Institute, The University of Tokyo, Yayoi, Bunkyo-ku, Tokyo 113-0032, Japan
This disaster was attributed to several factors. The earthquake was huge and such a giant earthquake was not expected in the Indian Ocean; thus tsunami warning system did not exist in the Indian Ocean; and consequently the coastal residents, tourists and governments did not have knowledge on tsunamis and were not prepared for such a disaster.

In the last decade, significant improvements have been made in earthquake and tsunami sciences as well as in their applications for disaster risk reduction. Scientific developments include real-time estimation of earthquake and tsunami source parameters, implementation of early warning of earthquakes and tsunamis, historical and geological studies of past earthquakes and tsunamis, examination of probable maximum earthquake size, long-term

\section{空}


forecast of large earthquakes, new types of tsunami observations in the open ocean and on the coast, and accurate tsunami modeling and inversion. The disaster risk reduction includes delivery of tsunami early warning messages to officials and coastal residents, making tsunami hazard maps or probabilistic hazard assessments, construction of infrastructure such as speakers to disseminate the warning messages, seawalls, evacuation signs, and designated evacuation areas, as well as public education. During the time period of such developments, the 2011 Tohoku earthquake and tsunami occurred and caused devastating tsunami damage in Japan and the Fukushima Dai-ichi Nuclear Power Station accident. Some of the above scientific developments helped to reveal the source characteristics of this giant earthquake and tsunami, yet they could not prevent the disaster.

In this review paper, I first describe the 2004 Indian Ocean tsunami in section 2, then review developments in seismology in section 3 , followed by those in tsunami science in section 4. The 2011 Tohoku earthquake and tsunami are described in section 5 . I then discuss efforts and issues that show how scientific developments can be utilized for disaster risk reduction in section 6 .

\section{The 2004 Indian ocean tsunami}

The source of the Indian Ocean tsunami was the Sumatra-Andaman earthquake on 26 December 2004 (Figure 1). The earthquake size, expressed by a moment magnitude scale $\left(M_{\mathrm{w}}\right)$, was 9.1 (according to United States Geological Survey: USGS), the largest in the world in the past 40 years. Moment magnitude is derived from seismic moment, which shows a physical size of the earthquake. The seismic moment of this single event was comparable to cumulative moment from global earthquakes in the preceding decade [1]. Only few earthquakes of this size $\left(M_{\mathrm{w}} \sim 9\right)$ occurred in the 20th century, and they were all around the Pacific Ocean. The 2004 Sumatra-Andaman earthquake was the first instrumentally-recorded event of this size in the Indian Ocean.

The 2004 earthquake was an interplate earthquake between the Indo-Australian plate and the Andaman (or Burma) microplate, a part of the Eurasian plate (Figure 1). The Indo-Australian plate subducts along the Sunda Trench at a rate of approximately $5 \mathrm{~cm}$ per year, and the direction of subduction changes from normal to the trench to oblique toward north. This subduction causes upper plate to be dragged and deformed up to a

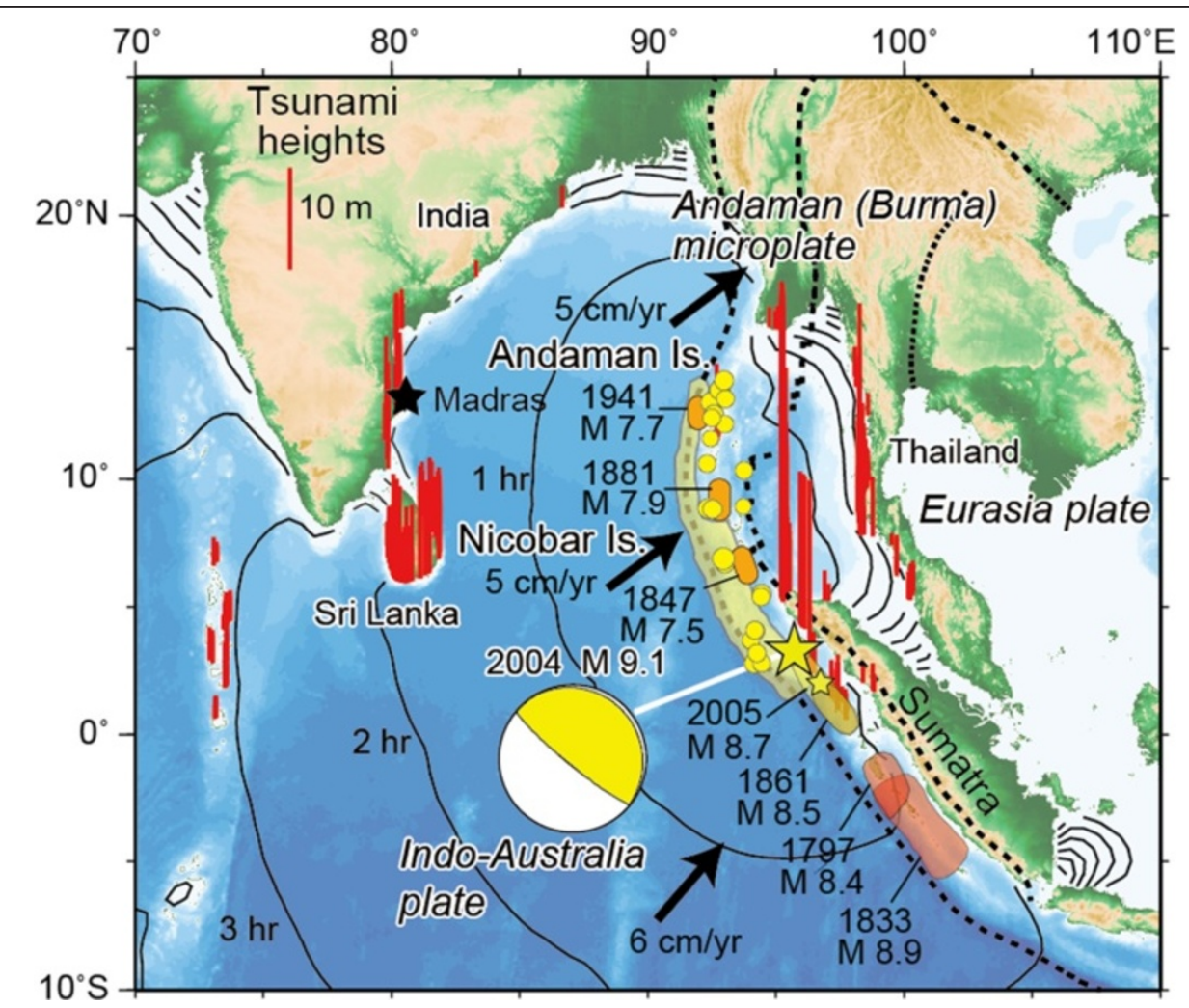

Figure 1 The 2004 Sumatra-Andaman earthquake. The tsunami heights measured by field surveys are shown by red bars (NOAA NGDC Tsunami Database). The yellow circles and beach ball show the one-day aftershocks and the focal mechanism. Computed tsunami fronts are shown for every hour. Black arrows indicate the direction and speed of Indo-Australian plate. Past earthquakes with their occurrence year and magnitudes are also shown with filled polygons and ovals. 
certain limit, then suddenly rebound to cause an interplate earthquake. The focal mechanism solution, estimated by Centroid Moment Tensor inversion [2] indicates a thrust faulting, or low-angle reverse fault, mechanism. The epicenter of the 2004 earthquake was located off Sumatra Island, but the source area extended northward through Nicobar to Andaman Islands.

The source lengths of the 2004 earthquake estimated from various data are somewhat different. Seismological analyses indicate that the 2004 rupture started at the epicenter off the west coast of Sumatra, then propagated toward north through Nicobar and Andaman Islands in about 500 seconds with a total length of 1200 to 1300 $\mathrm{km}[1,3]$. The fault slip was largest, 20 to $30 \mathrm{~m}$, off the coast of northern Sumatra, followed by $\sim 5 \mathrm{~m}$ slip off Nicobar Island. The fault slip around the Andaman Islands was estimated to be small and was speculated to be slow. The analysis of tsunami waveforms recorded on tide gauge stations [4] showed a shorter, up to $900 \mathrm{~km}$, source of the tsunami. Satellite image analyses and ground-truth field investigations [5-7] indicated that the coseismic coastal sea level change extended from Sumatra through North Andaman Island with a total length of $1600 \mathrm{~km}$. Some of the northern slip is attributed to afterslip on the fault plane which occurred up to 40 days [8].

This earthquake generated a tsunami which devastated the shores of the Indian Ocean. Within 30 minutes of the earthquake, the tsunami first attacked Banda Aceh and other coastal villages of Sumatra Island in Indonesia causing 160,000 casualties. The tsunami then reached the coasts of Thailand (casualty 8000$)$, Sri Lanka $(35,000)$ and India $(16,000)$ within approximately two hours. About a half of tsunami victims in Thailand were foreign tourists. The tsunami further propagated and reached the east coast of Africa where it caused 300 casualties in Somalia. The total casualties of the Indian Ocean tsunami were more than 200,000.

The distribution of the 2004 tsunami heights, measured by scientists and engineers from many countries, looks proportional to the damage distribution (Figure 1). The tsunami heights were mostly larger than $20 \mathrm{~m}$ with a maximum height above $30 \mathrm{~m}$ near Sumatra Island, particularly in the Aceh province. The tsunami heights along the Andaman Sea coast varied greatly; 5 to $15 \mathrm{~m}$ near Thailand but less than $3 \mathrm{~m}$ near Myanmar. The tsunami heights were up to $5 \mathrm{~m}$ in Andaman Islands. In Sri Lanka, the tsunami heights were 5 to $15 \mathrm{~m}$.

The tsunami was instrumentally recorded by coastal tide gauges in the Indian Ocean as well as in the Atlantic and Pacific Oceans [9]. The tsunami propagation in deep water was captured by deep-sea pressure gauges [10], satellite altimeters [11], hydrophones [12] and horizontal components of broad-band seismographs [13].
At the time of the 2004 tsunami, the tsunami warning system existed only in the Pacific Ocean. The Pacific Tsunami Warning Center (PTWC), located in Hawaii, issued the first information bulletin only 15 minutes after the earthquake. The earthquake was located off the west coast of Northern Sumatra, and the magnitude was initially estimated to be 8.0. The second bulletin was issued at 69 minutes after the earthquake, but still before the tsunami arrivals at the coasts of Thailand, Sri Lanka and India. The earthquake size was updated to 8.5 and the possibility of a local tsunami was included in the bulletin. However, these messages did not reach the governments or coastal communities around the Indian Ocean [14].

The 2004 tsunami caused slight damage to Madras Atomic Power Station at Kalpakkam, near Chennai, on the east coast of India. This was the first tsunami damage to a nuclear power plant in the world. At about 3 hours after the earthquake, the tsunami arrived at the nuclear power station with $4.5 \mathrm{~m}$ height, and caused flooding of the seawater pump house and construction site of a new reactor. The switchboard of the pump house was submerged, but the reactors were safely shut down. After this accident, International Atomic Energy Agency revised their safety guide [15].

\section{Review of developments in seismology}

Can we forecast earthquakes and tsunamis in advance? Earthquake source is a fault motion, which is movement or rupture across a plane within the earth. Sudden fault motion generates seismic waves which cause ground shaking and seafloor displacement which becomes the source of tsunami. If we can forecast future earthquakes, or tell in advance where, when and how big they will be, it would benefit to reduce damage from earthquakes and tsunamis. Earthquake and tsunami forecast is made at various time scales; in seconds or minutes between fault rupture and arrival of seismic waves (called Earthquake Early Warning, EEW), in minutes to hours between the earthquake occurrence and the first tsunami arrival (Tsunami Warning), in hours, days or months before the earthquake (Short-term earthquake prediction), and in years to decades before earthquake (Long-term earthquake forecast).

The EEW system forecasts ground shaking after the earthquake occurrence but before the arrival of seismic waves, based on quick analysis of seismic data recorded near the earthquake source $[16,17]$. The EEW was developed before 2004 but has been implemented and in operation in the last decade in several countries such as Japan [18]. Typical lead time between the announcement and start of large ground shaking is from several to several tens of seconds, yet providing useful information through TV, radio or cell phones. 
The current tsunami warning system also relies on quick analysis of seismic data. The recent deployment of advanced seismological analysis methods for rapid determination of earthquake source parameters, such as the $W$ phase analysis [19], makes it possible to quickly assess an earthquake's size with acceptable accuracy and to estimate the potential tsunami size, in order to issue tsunami warnings in less than half an hour for global earthquakes. For example, during the 2012 Sumatra earthquake, PTWC issued bulletins with not only earthquake parameters but also tsunami amplitudes predicted by simulation-based empirical formula [20]. Thus tsunami warning is practically possible at least for far-field tsunamis. Accurate near-filed tsunami warning is still challenging as discussed in next sections.

Earthquake prediction depends on monitoring reliable precursory phenomena which are yet to be discovered. In the rest of this section, we limit our discussion on long-term forecast, which are commonly expressed as future probabilities of occurrence.

Probabilities of future earthquakes can be estimated from past earthquake data. Earthquake probabilities in a certain time window, for example in the next 30 years, can be calculated by fitting inter-earthquake times with a probabilistic density function. If earthquakes occur randomly in time, or a fault does not have any memory of past earthquakes, the Poisson process is assumed to compute the time-independent probabilities; i.e., the probability of the next earthquake is constant through time, depending solely on the average recurrence interval. Alternatively, earthquake probabilities may increase with time, if similar size earthquakes recur more or less regularly (called characteristic earthquakes). The elastic rebound theory explains that an earthquake occurs when the accumulated stress at the plate boundary reaches certain limit. In such a case, statistical distributions such as log-normal distribution or Brownian passage model $[21,22]$, with the average recurrence interval and the date of most recent events, are used to calculate the time-dependent probabilities.

Was the 2004 Sumatra-Andaman earthquake the first mega-event in the region? Seismological data indicate that earthquakes with $M 7.5$ and 7.9 occurred in the Nicobar Islands and an $M 7.7$ earthquake occurred in the Andaman Islands in 1941 [23]. These past earthquakes had been considered as the maximum earthquakes in the Andaman and Nicobar Islands. Instrumental seismological data are available since the last century. Historical records of damage from past earthquakes or tsunamis are kept for more than 1000 years in some countries like China or Japan $[24,25]$. In other places, such historical earthquake data exist only for less than a few centuries, which may not be long enough to record the history of large earthquakes. Geological records such as traces of coastal sea level change or deposits brought by tsunami, called tsunami deposit, are used to study older earthquakes. Such a study area is called paleoseismology.

Paleoseismological studies of tsunami deposits have been conducted since 2004 in Sumatra Island [26], Thailand [27-29], the Andaman and Nicobar Islands [30,31] and India [32]. These studies have shown geological evidence of past tsunamis in the regions. The last earthquake was estimated to have occurred around AD 1300-1450 in Thailand, AD 1290-1400 in Sumatra, AD 1250-1450 near the Andaman and Nicobar Islands, post AD 1600 in South Andaman Island, and around AD 1020-1160 along the Indian coast. These various dates may indicate that the last great earthquake was not exactly the same as the 2004 Sumatra-Andaman earthquake.

Besides the studies of past earthquakes in particular regions, seismologists have attempted to make global assessments of probable maximum earthquake size. Because of infrequent nature of such giant earthquakes, global collection of data is needed to increase our sample and knowledge on such large earthquakes. A comparative studies of subduction zones [33] showed that there are two end members of subduction zones, i.e., Chilean type and Mariana type, among which only the former types can produce great earthquakes. Subsequent studies proposed that the age of subducting plate and plate convergence rate may control the maximum size of earthquakes [34]; larger earthquakes occur in subduction zones where younger plate subducts at a higher convergence rate. However, re-examination of the relation among the plate age, convergence rate and the maximum earthquake size, made after the 2004 earthquake, showed that such a relationship is not as strong as it was believed before [35].

One way to calculate earthquake probability is to assume that the maximum earthquake size is $M 9.5$, which is the size of the 1960 Chile earthquake, the largest earthquake in the $20^{\text {th }}$ century (Figure 2a). For example, McCaffrey [36] proposed that any subduction zone in the world could produce an $M \sim 9$ earthquake. But was the 1960 Chile earthquake really the maximum earthquake? It should be noted that the size of the 1960 Chile earthquake was estimated in the 1970's [37]. Recently, Matsuzawa [38] proposed that we should prepare for an $M \sim 10$ earthquake, although the maximum size of an earthquake on the earth could be $M \sim 11$.

Variability in size and recurrence interval is likely a characteristic nature of great earthquakes in subduction zones [39]. Historical and geological data in other subduction zones indicate that recurrence patterns of past great earthquakes are highly variable (Figure $2 b$ ). For example, in southern Chile, historical records indicate that past earthquakes occurred in 1575, 1737, 1837 and 1960 , with an average recurrence interval of 130 years. 


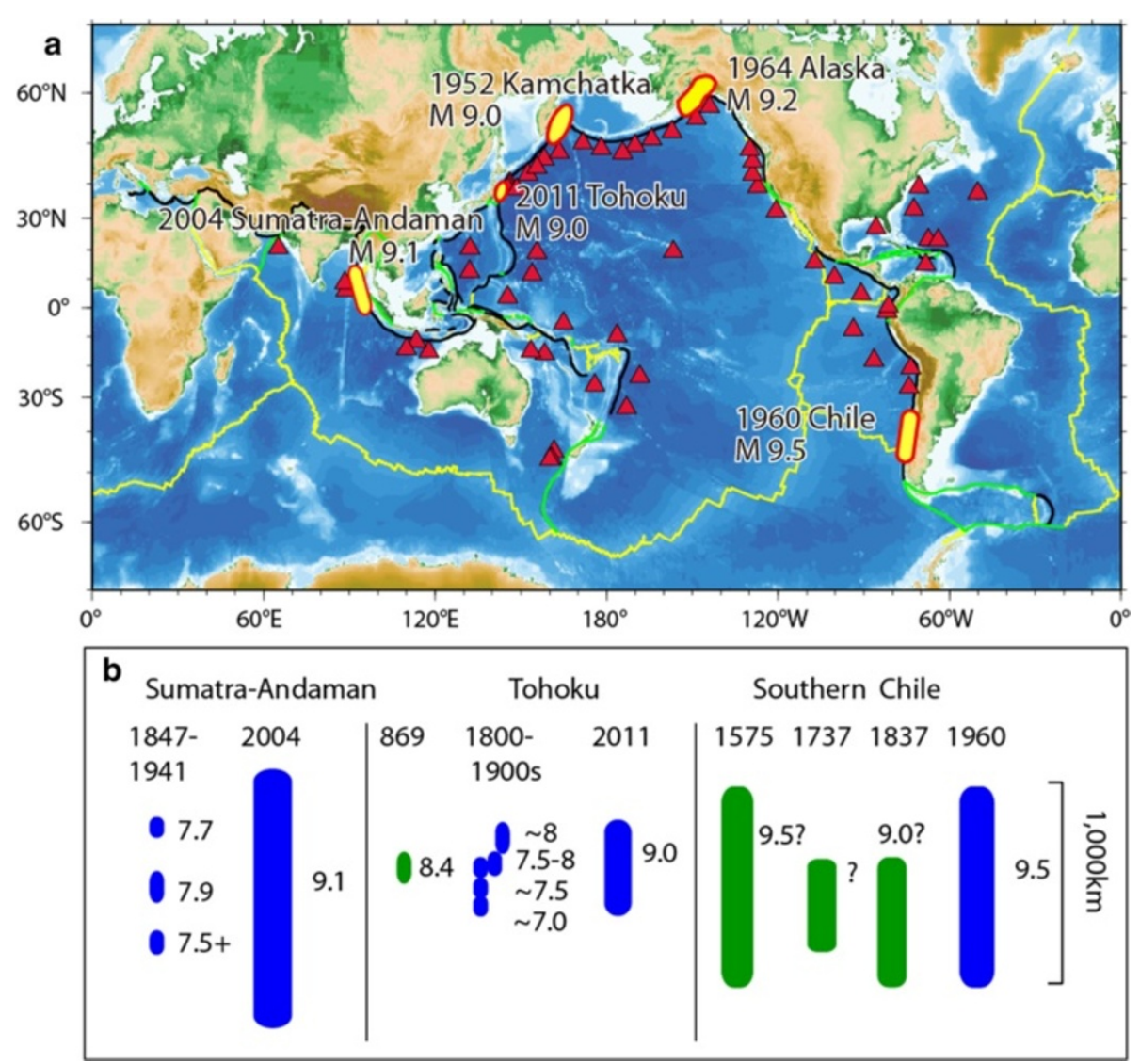

Figure 2 Giant earthquakes in the world. (a) The locations of $M \sim 9$ earthquakes since the $20^{\text {th }}$ century are shown by yellow ovals. Red triangles indicate DART stations. Black, yellow and green colors indicate three kinds of plate boundaries, i.e., subduction zones, mid-oceanic ridges and transform faults. (b) Variability of earthquake size in subduction zones. The colored bars represent simplified rupture area: blue, inferred solely from instrumental and written records; green, includes paleoseismological evidence. Numerals denote moment magnitudes. Updated from Satake and Atwater [39].

However, the geological evidence or tsunami deposits were found only from the 1960 and 1575 earthquakes as well as older earthquakes, yielding the recurrence interval of $\sim 300$ years based on paleoseismological studies [40]. The 2011 Tohoku earthquake added another example of such variability.

\section{Review of developments in tsunami science}

Tsunamis are generated by submarine earthquakes, volcanic eruptions or landslides. For the earthquake source, vertical displacement due to subsurface faulting, which can be computed from earthquake source parameters [41] are usually considered as the tsunami source. For the case of the 2004 Sumatra-Andaman earthquake, seafloor was uplifted on the western edge and subsided on the eastern edge of the source area. This asymmetric seafloor deformation yielded initial receding wave on the east (e.g., Thailand) whereas the water level initially rose on the west (e.g., Indian or Sri Lankan coasts). When the tsunami source is on a steep seafloor slope and the horizontal displacement is large, the vertical movement of water due to the horizontal displacement of the slope must be also considered [42]. For the 2011 Tohoku tsunami, the large horizontal displacement of seafloor slope was responsible for $20-40 \%$ of the observed tsunami amplitudes [43]. While tsunami is generally larger for larger earthquake, notable exceptions are "tsunami earthquakes" which generate much larger tsunamis than expected from seismic waves [44,45]. Typical examples are the 1896 Sanriku earthquake which produced much smaller ground shaking than the 2011 Tohoku earthquake, but the tsunami heights on Sanriku coasts from these earthquakes were similar [46]. More recent examples of "tsunami earthquake", such as the 1992 Nicaragua earthquake and the 2010 Mentawai earthquakes, indicate that very large slip near the trench axis is responsible for the large tsunami and smaller seismic waves $[47,48]$.

Tsunamis are instrumentally recorded by sea level recorders such as coastal tide gauges, near-shore wave and GPS buoys, and deep-ocean bottom pressure gauges (Figure 3). Coastal tide gauges have various types such as mechanical type with a float, and pressure, acoustic 


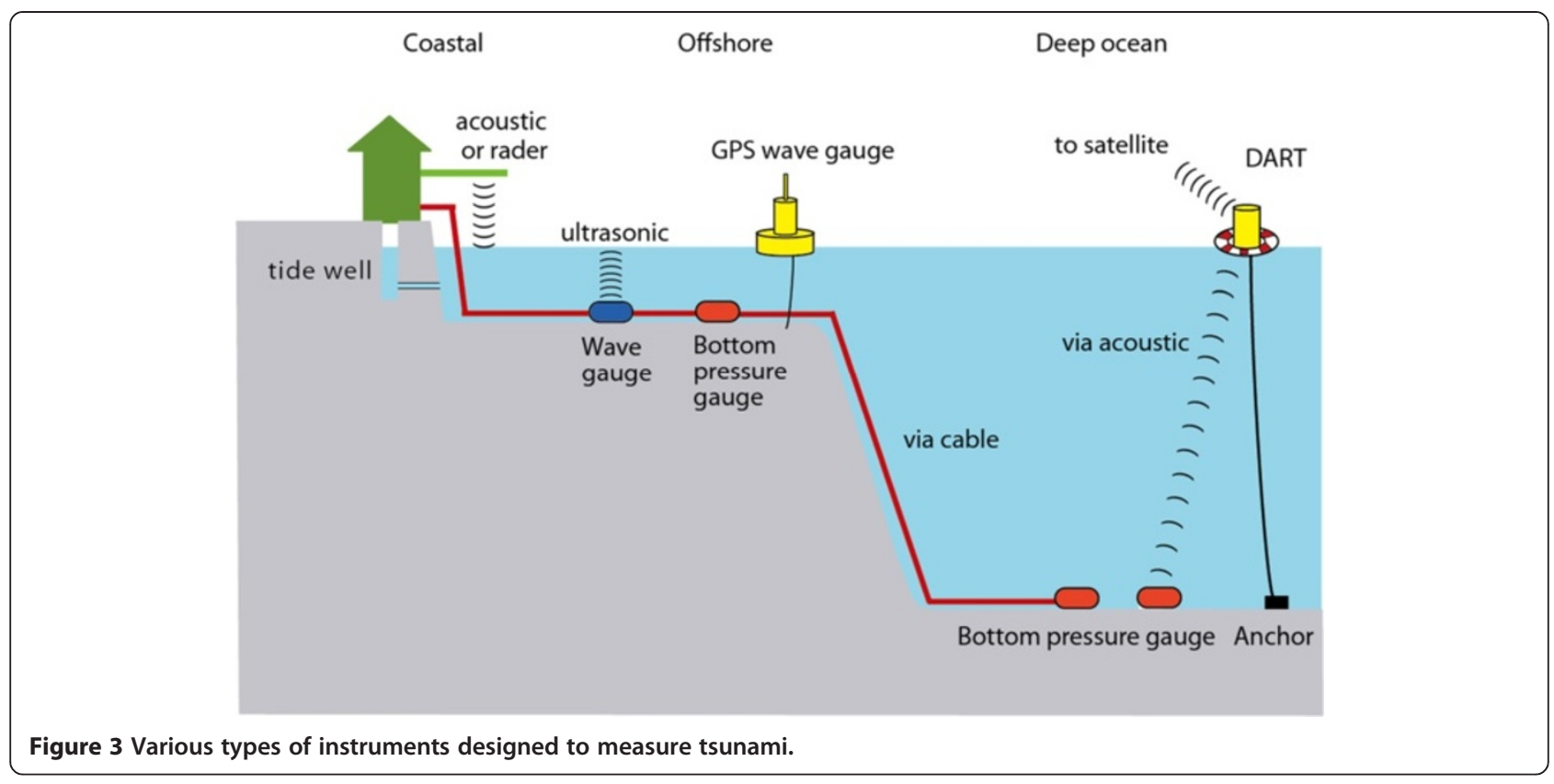

or radar sensors. After the 2004 Indian Ocean tsunami, more coastal tide gauges have been installed in the Indian Ocean region. Currently, sea level data at several hundreds of stations are available in real-time (e.g., http://www.iocsealevelmonitoring.org/). Near-shore gauges include wave gauges using ultrasonic waves and GPS buoys. They measure offshore sea levels at water depths of 50 to $200 \mathrm{~m}$, and can detect tsunamis before their coastal arrivals giving some lead time for issuing tsunami warnings. Tsunami waveforms are much simpler in deep oceans, where they are free from the effects of coastal reflection or refraction due to bathymetry. A kinematic GPS analysis of a ship in open ocean detected the 2010 Chile tsunami [49]. Deepocean measurements of tsunamis have been made by using bottom pressure gauges for early detection and warnings of tsunamis. The Deep-ocean Assessment and Reporting of Tsunamis (DART), developed by NOAA (National Oceanic and Atmospheric Administration) of the USA, records water levels using bottom pressure gauges, and sends signals to a surface buoy via acoustic telemetry in the ocean, then via satellites to a land station in real time [50]. After the 2004 Indian Ocean tsunami, the total number of DART stations in the Pacific as well as Indian Ocean increased from 6 in 2004 to about 60 in 2013 [51]. An alternative way to retrieve data from deep ocean bottom pressure data is to use submarine cables. Around Japan, more than 10 bottom pressure gauges were installed at the time of the 2011 Tohoku earthquake, and more cabled networks, DONET along the Nankai trough [52] and S-net along the Japan Trench [53] are being deployed.

Tsunami can be hydrodynamically considered as shallowwater (or long) waves, whose phase velocity is given as a square root of product of water depth and the gravitational acceleration. Because the ocean depth, or bathymetry, is globally surveyed and mapped, the tsunami propagation can be simulated using the actual bathymetry data. A popular method of tsunami numerical simulation is a finite-difference computation of equation of motion for shallow-water waves (momentum conservation) and the equation of continuity (mass conservation) [54]. For deep ocean, a typical grid size is a few to several kilometers. Near the coasts with shallow depths, non-linear effects and bottom friction need to be included. In addition, effects of local topography and bathymetry, such as reflection or refraction, also play important role, hence the smaller grid, typically with several tens of meter interval, is adopted. For computation of tsunami inundation on land, topographic data are also used with moving boundary conditions [55].

The tsunami waveform data are used to estimate the water height, or fault slip, distribution at the source. In this method, called tsunami waveform inversion [56], the tsunami source or fault plane is divided into subfaults, and tsunami waveforms, or the Green's functions, are computed for each of the subfault with unit amount of slip. Assuming that the observed tsunami waveforms are linear superposition of the Green's function, the distribution of displacement or fault slip can be estimated using a least-square method. The tsunami waveform inversion is used to study the tsunami sources. For the 2011 Tohoku earthquake, because high-quality and high-sampling offshore tsunami waveforms were available, the temporal change as well as spatial distribution of the slips on subfaults was estimated [43]. 
The tsunami waveform inversion has been also used for tsunami warning systems, both far-field and near-field. The current tsunami warning system, based on seismic monitoring, first determines location, depth, and magnitude of earthquake, then predict tsunami arrival time and coastal heights using database of pre-computed tsunami waveforms for various earthquake sources [57,58]. For far-field tsunami warnings, the tsunami waveforms at the DART locations are computed for numerous tsunami sources around the Pacific Ocean. When the DART stations record tsunami waveforms, they are compared with pre-computed tsunami waveforms to first estimate the tsunami sources. Then, the estimated sources are used to predict tsunami arrival times and the amplitudes at more distant locations. The predicted tsunami waveforms from the real-time data assimilation, without assuming earthquake source parameters, show good agreement with the observed waveforms [59].

For the near-field tsunami warning, tsunami waveforms recorded on cabled bottom pressure gauges can be used to estimate the sea surface displacement rather than the fault slip [60,61]. This method, called tFISH (tsunami Forecasting based on Inversion for initial seaSurface Height), would be useful for tsunami warning if the cabled stations are densely distributed. The same method can be applied to data on near-shore GPS buoys [62]. Combined with Real-time Automatic detection method for Permanent Displacement (RAPiD) of landbased GPS data, the method can predict tsunami arrival time and wave heights at least 5 minutes before tsunami arrival for near-field tsunamis [63]. Forecasting tsunami inundation on land can be made by comparing the computed near-shore tsunami waveforms from actual earthquake source parameters with those pre-computed and stored in the database [64].

For recent trans-Pacific tsunamis, such as the 2010 Chile tsunami or the 2011 Tohoku tsunami, discrepancies (a few percent) in the travel time between the observed waveforms recorded at DART stations and the computed waveforms based on linear shallow water have been reported. A small reduction of the tsunami phase velocity at very long period (>1000 seconds), caused by the coupling of seawater and self-gravitating elastic Earth, is considered to be responsible for these delays [65].

\section{The 2011 Tohoku earthquake and tsunami}

A giant earthquake occurred off the northern coast of Honshu, Japan, on 11 March 2011. With the largest magnitude $\left(M_{\mathrm{w}} 9.0\right)$ in the history of Japan, it caused a devastating tsunami disaster and serious damage to the nearby Fukushima Dai-ichi Nuclear Power Station. The earthquake and subsequent tsunami caused approximately 18,500 dead and missing persons. The 2011 Tohoku earthquake occurred at the Japan Trench where the
Pacific plate subducts beneath northern Honshu at a rate of approximately $8 \mathrm{~cm}$ per year. This earthquake was also an interplate earthquake with a thrust-type fault motion.

Very dense geophysical measurements both on land and offshore Japan made this event the best recorded subduction-zone earthquake in the world (Figure $4 \mathrm{a}$ ). The nation-wide land-based GPS network with more than 1000 stations recorded large coseismic movements with a maximum amount of $5.3 \mathrm{~m}$ eastward and $1.2 \mathrm{~m}$ downward [66]. The repeated marine geophysical measurements, such as GPS/acoustic positioning, bottom pressure gauge, or multi-beam swath bathymetry survey, started before the 2011 Tohoku earthquake, detected huge seafloor displacement, approximately $50 \mathrm{~m}$ in horizontal direction [67-69].

The 2011 tsunami was first detected on ocean bottom pressure and GPS wave gauges. A cabled bottom pressure gauge about $76 \mathrm{~km}$ off Sanriku coast at a $1600 \mathrm{~m}$ water depth recorded $\sim 2 \mathrm{~m}$ water rise in about 6 minutes starting immediately after the earthquake, followed by an impulsive wave with additional $3 \mathrm{~m}$ rise within 2 minutes [72]. Similar two-stage tsunami waveforms were also recorded on a GPS wave gauge near the coast 12 minutes later, just before tsunami arrival on the coast (Figure 4b).

The Japan Meteorological Agency (JMA) issued the first tsunami warning 3 minutes after the earthquake. The estimated tsunami heights were at maximum $6 \mathrm{~m}$, significantly smaller than the actual tsunami heights with a maximum of $40 \mathrm{~m}$ [73]. The smaller expected coastal tsunami heights were due to the initial underestimation of the earthquake magnitude $(M=7.9)$. Nevertheless, very strong ground shaking and the tsunami warning urged many coastal residents to evacuate to high ground and thus saved their lives. After detecting the large offshore tsunami on GPS wave gauges, JMA upgraded the tsunami warning messages to a higher level of estimated tsunami heights at 28 minutes after the earthquake. Although it was announced before the actual tsunami arrival to the nearest coast, the updated warning messages did not reach all the coastal communities due to power failures and the fact that coastal residents had already started evacuation.

The occurrence of an $M \sim 9$ earthquake near the Japan Trench was another surprise to the global seismological communities. Off Miyagi prefecture, near the epicenter of the 2011 Tohoku earthquake, large $(M \sim 7.5)$ earthquakes have repeatedly occurred since 1793 with an average interval of 37 years. On the basis of this recurrence, the Earthquake Research Committee of the Japanese government estimated the probability of a great $(M \sim 8)$ earthquake occurring between 2010 and 2040 as 99\% [74]. The longterm forecast failed to predict the size $(M)$ of the Tohoku earthquake [75].

The Sanriku coast of Tohoku had been devastated by previous tsunamis. The 1896 Sanriku earthquake, a typical 


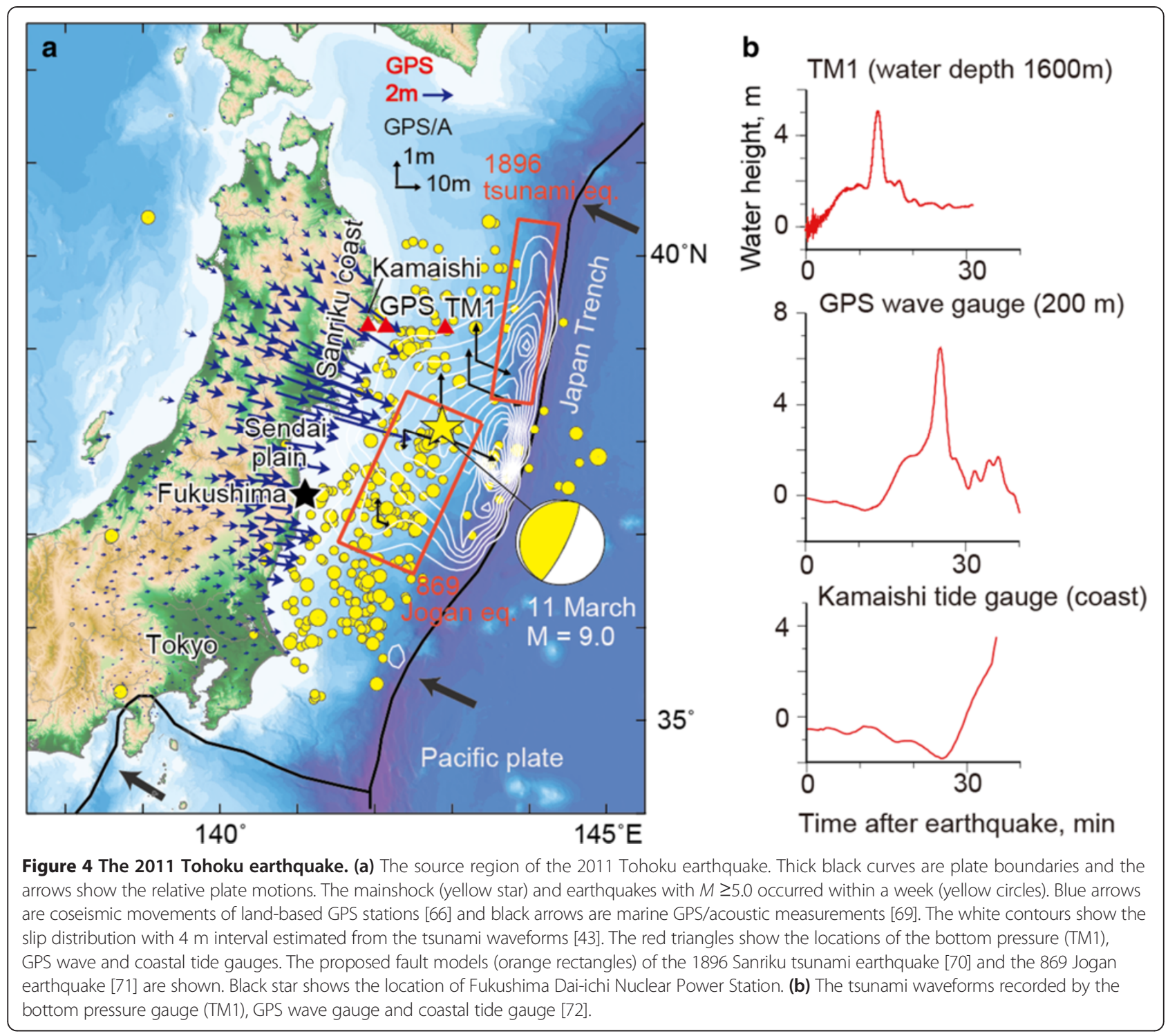

"tsunami earthquake," caused large tsunami, with the maximum height of $38 \mathrm{~m}$, despite its weak ground shaking. The 2011 tsunami heights along the Sanriku coast were as high as nearly $40 \mathrm{~m}$, roughly similar to the 1896 tsunami heights [46]. The 1896 tsunami caused about 22,000 casualties, slightly more than the 2011 tsunami. Study of tsunami waveforms indicate that the 1896 earthquake was generated from a fault motion near the trench axis [70], similar to other "tsunami earthquakes."

The predecessor of the 2011 Tohoku earthquake is considered to be the 869 Jogan earthquake [71,76]. A national history book depicts strong ground shakings, collapse of houses, kilometers of tsunami flooding with 1000 drowned people in Sendai plain in AD 869 in Jogan era. In addition, paleoseismological studies found tsunami deposits in coastal lowlands, more than $4 \mathrm{~km}$ from the current coast in the Sendai plain. Older tsunami deposits were also found. From the distribution of the tsunami deposits and computed inundation area, the size $(M=8.3$ to 8.4$)$, location and fault models of the Jogan earthquake were proposed with a recurrence interval between 500 and 1000 years [71,77].

Tsunami models indicate that the source of the 2011 earthquake appear to be a combination of the 1896 Sanriku "tsunami earthquake" and a Jogan-type deeper interplate earthquake [43,72]. A huge slip near the trench axis, similar to the 1896 Sanriku tsunami earthquake, caused the first impulsive tsunami waves recorded by the bottom pressure and GPS wave gauges and large tsunami runup heights along Sanriku coast [46]. The fault motion and large slip along the deeper plate interface, similar to a proposed model of the Jogan earthquake [71], produced a long-wavelength seafloor displacement which caused the first gradual rise at offshore gauges (Figure 4b) 
and the large tsunami inundation in the Sendai plain $[78,79]$.

The 2011 tsunami also impacted four nuclear power stations located near the source area. At these stations, the strong ground shaking automatically shut down the reactors, and the diesel power generators started to cool down the reactors. At the Fukushima Dai-ichi Nuclear Power Station, strong ground shaking damaged the external power supply system, and the $15 \mathrm{~m}$ tsunami damaged the diesel generator. The Fukushima Dai-ichi Station thus failed to cool down the reactors, which led to melt down of three reactors, hydrogen explosions and release of radioactive materials into atmosphere [80], ocean [81], and land/soil [82]. At the other three nuclear power stations, the reactors were cooled down by using external or backup power and succeeded to avoid fatal accident.

The estimated maximum tsunami, or design tsunami height, at the Fukushima Dai-ichi Nuclear Power Station was $6.1 \mathrm{~m}$, based on the $M 7.5$ earthquake which occurred in 1938. The long-term forecast of Earthquake Research Committee indicated that a "tsunami earthquake" may occur anywhere along the Japan Trench. The tsunami height at the Fukushima Dai-ichi Station from the Jogan earthquake model was estimated as $8.9 \mathrm{~m}$, and that from a "tsunami earthquake" off Fukushima was calculated as $15.7 \mathrm{~m}$ by Tokyo Electronic Power Company, but no preventive actions were taken. For critical facilities such as a nuclear power plant, the seismological progress should be closely monitored and reflected in safety preparedness.

\section{Toward tsunami disaster risk reduction}

Despite advances in natural science on hazards, why do disaster losses continue to increase? This is a motivation to initiate an international and interdisciplinary program called IRDR (Integrated Research for Disaster Reduction) under ICSU (International Council for Science), together with ISSC (International Social Science Council) and UN International Strategy for Disaster Reduction (UN-ISDR). Disaster risk consists of hazard and vulnerability. Natural hazard such as earthquake or tsunamis cannot be controlled, but may be forecasted. However, disaster risk can be reduced by minimizing vulnerability or exposure to hazards. The disaster risk reduction is therefore closely related to how science can be utilized for safety of the society.

In January 2005, immediately after the 2004 Indian Ocean tsunami, Hyogo Framework of Action (HFA) for 2005-2015 was adopted at the World Disaster Reduction Conference and later endorsed by UN General Assembly. It is for building the resilience of nations and communities to disasters, and consists of five action items. (1) Make disaster risk reduction a national and local priority; (2) Identify, assess and monitor disaster risks and enhance early warning; (3) Use knowledge, innovation and education to build understanding and awareness; (4) Reduce risk factors; and (5) Be prepared and ready to act. We will review how the scientific developments can contribute to these actions.

The tsunami early warning systems have been implemented in the Indian Ocean and other ocean basins. In the Pacific Ocean, an international tsunami warning system was established after the 1960 Chile tsunami, and International Coordination Group was formed under UNESCO Intergovernmental Oceanographic Commission. Following the 2004 Indian Ocean tsunami, similar groups were formed for the Indian Ocean, for the North-eastern Atlantic and Mediterranean Sea, and for the Caribbean Sea. In coordination with the UNESCO group, three regional Tsunami Warning Centers were recently established in Australia [83], India [84] and Indonesia [85]. These centers are staffed 24 hours a day and 7 days a week to monitor seismic activity and the possibility of a tsunami occurrence. The warning systems rely on the most advanced seismic and sea-level monitoring, a database of past tsunami events, and pre-made numerical simulations. These systems can issue tsunami warning messages typically about 5 minutes after an earthquake.

Once the coastal residents receive tsunami warning message, they need to know what it means, and where to evacuate. Tsunami is a Japanese word meaning "harbor wave," but few people around the Indian Ocean knew the word before the 2004 Indian Ocean tsunami. It has been used internationally since the 2004 Indian Ocean tsunami. An effective tool to guide coastal residents for evacuation is a hazard map showing the tsunami risk zones. Possible flooding zones and safe evacuation places such as tsunami shelters can be shown in the hazard maps. One of the lessons learned from the 2004 Indian Ocean tsunami is that not only coastal residents but also foreign tourists need to be informed about tsunami hazards. In the Hawaiian Islands, tsunami hazard maps are prepared and published in the local phone books that are available at every hotel room. Those in high-rise hotel buildings are advised to move vertically to the third or higher floors, rather than horizontally moving out of the possible flooding area.

Tsunami hazard maps are constructed for past tsunamis or for the most likely tsunami source. In the Sendai plain before the 2011 Tohoku tsunami, tsunami hazard maps and other countermeasures were prepared for an $M \sim 8$ earthquake, which was estimated to occur with $99 \%$ probability in the next 30 years (see The 2011 Tohoku earthquake and tsunami section). The predicted inundation area was, for the most part, within $1 \mathrm{~km}$ from the coast, and much smaller than the actual tsunami inundation area of the $2011 M=9.0$ earthquake which was up to $5 \mathrm{~km}$. The distribution of the 869 Jogan tsunami deposits, however, was similar to the inundation area of the 2011 Tohoku 
tsunami. The hazard maps need to consider such infrequent gigantic earthquake and tsunamis.

One of the developments in tsunami hazard assessment in the last decade is Probabilistic Tsunami Hazard Assessment (PTHA) [86,87]. Results of the PTHA are typically displayed as hazard curves that show the annual frequency of exceedance of tsunami heights. The hazard from a large number of possible sources including nonearthquake source can be aggregated together to develop a tsunami hazard curve. In addition, multiple sources of uncertainty related to the source parameters and tsunami numerical computations can be considered in the PTHA. Uncertainty can be classified into two types: aleatory and epistemic. Aleatory uncertainty, or random variability, relates to the natural or stochastic uncertainty inherent in a physical system, and cannot be reduced but can be estimated from repeated observations or experiments. Epistemic uncertainty is due to incomplete knowledge and data, and can be reduced by the collection of new data. Epistemic uncertainty can be treated as logic trees [88]. A single hazard curve is obtained by integration over the aleatory uncertainties, and a large number of hazard curves are obtained for different branches of a logic-tree representing epistemic uncertainty. The PTHA for Fukushima Dai-ichi Nuclear Power Station estimated that the annual exceedance of $10 \mathrm{~m}$ high tsunami was an order of $1 \times 10^{-5}$, or return period of around 100,000 years [89].

To reduce social vulnerability, various infrastructures, or hardwares, have been implemented since the 2004 Indian Ocean and 2011 Tohoku tsunamis. Speakers to broadcast tsunami warning messages have been installed in coastal areas of Indonesia or Thailand. Sign boards showing the altitude and route to evacuation places have been installed at numerous coastal communities in the world. New and higher seawalls have been constructed for coastal cities, particularly to protect critical facilities such as nuclear power plants. These kinds of infrastructure have their lifetime and may not be maintained until the next tsunami disaster.

Soft measures to reduce vulnerability include education and awareness efforts. Numerous books and videos have been published and used for education. In Japan, a famous story, called "Inamura-no-hi" (fire of rice sheaves), has been used for tsunami education. After a strong earthquake was felt at a coastal village in 1854, the village chief put fire on his just-harvested rice crops to guide villagers to high ground and to save their lives. Another concept, "Tsunami tendenko," which calls for a quick tsunami evacuation without waiting for others, not even one's parents or children, became famous and popular after the 2011 tsunami [90,91]. Periodic practice and drills are also important to keep the tsunami warning and mitigation system functional. In Indonesia, tsunami evacuation drills have been carried out in many communities including Banda Aceh, Padang and Bali in the last decade.

Interdisciplinary studies of natural, social and human sciences, as well as trans-disciplinarity of science, that is cooperation between scientist and society, are important for disaster risk reduction. For the latter, results of scientific developments need to be shared with and utilized by various stakeholders such as national government, local government or communities (Figure 5).

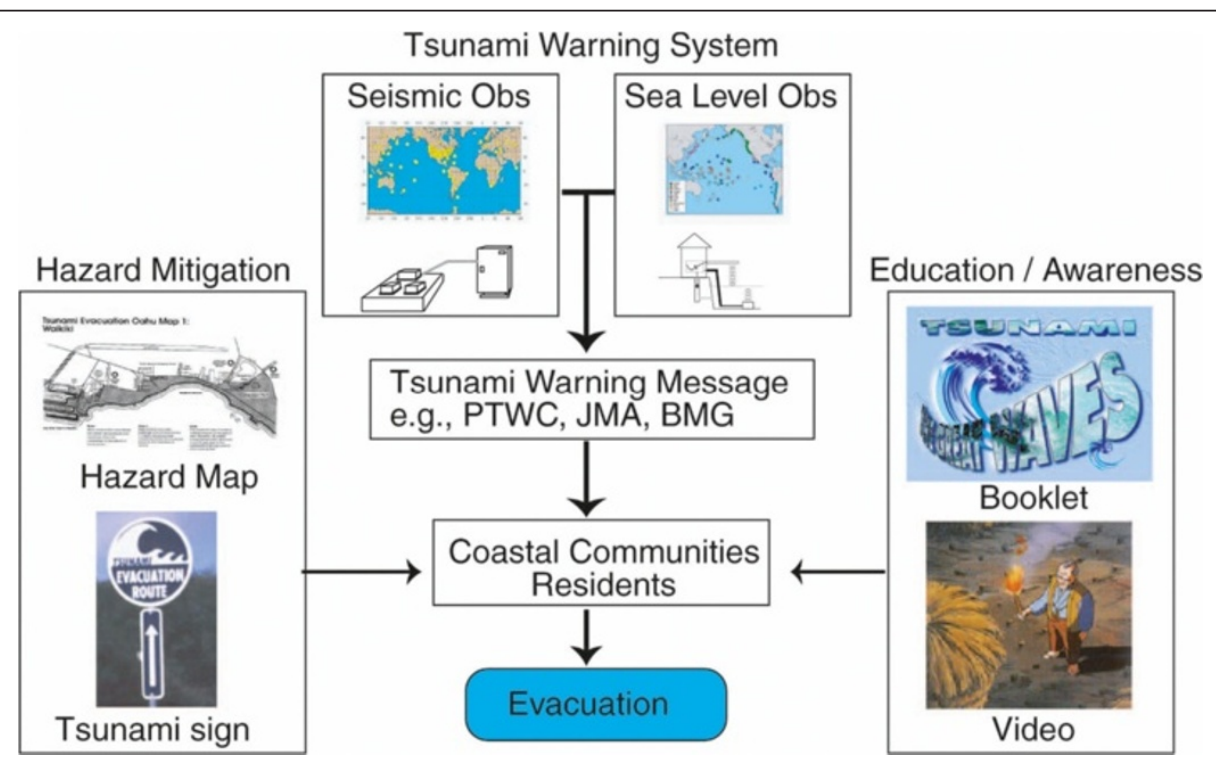

Figure 5 Elements of a tsunami-resilient society. Tsunami warning system (center), hazard assessment (left) and education systems (right) to reduce tsunami disaster risks. 


\section{Conclusions}

(1) The 2004 Sumatra-Andaman earthquake, the largest event in the last 40 years, caused the worst tsunami disaster in countries around the Indian Ocean. The main factors for the disaster were unexpected occurrence of a gigantic earthquake in the region and lacks of tsunami warning system, education and awareness for tsunamis in the Indian Ocean.

(2) Seismological developments since 2004 include early detection and estimation of tsunami occurrence, paleoseismological studies on evidence of similar tsunamis in the past, and global studies of recurrence nature of large earthquakes in subduction zones. The assessments of probable maximum size and long-term forecast of great subduction zone earthquakes still appear to be complicated, because of variability of recurrent earthquakes.

(3) Developments in tsunami science include accurate modeling of tsunami source such as contribution of horizontal components or "tsunami earthquakes", instrumental developments for offshore and deepocean tsunami observation, deployments of DART gauges in the Pacific and other oceans, improvements in tsunami propagation modeling, and real-time inversion of various kinds of data for the tsunami warning.

(4) At the time of the 2011 Tohoku earthquake, the tsunami warning issued in 3 minutes of the earthquake saved many lives yet resulted in 18,500 casualties. The long-term earthquake forecast made before 2011 estimated the 30 year probability of 99 $\%$ in the source region with smaller $(M \sim 8)$ size. The source of the 2011 earthquake was modeled as a combination of the 1896 "tsunami earthquake" and the 869 Jogan earthquake.

(5) Towards tsunami disaster reduction, the development of seismology and tsunami science can be implemented as tsunami early warning systems, tsunami hazard maps, and probabilistic tsunami hazard assessments. In addition, interdisciplinary and trans-disciplinary approaches are needed for scientists with other stakeholders.

\section{Competing interests}

The author declares that he has no competing interests.

\section{Authors' contributions}

This is a single-authored paper, and the no other person has contributed to this manuscript.

\section{Acknowledgements}

The author acknowledges Drs. Shingo Watada and Mohammad Heidarzadeh for their reviews of the manuscript before submission. Valuable comments and suggestions by two anonymous reviewers also improved the paper. This work was partially supported by KAKENHI (24241080).
Received: 9 September 2014 Accepted: 4 November 2014

Published online: 13 November 2014

\section{References}

1. Lay T, Kanamori H, Ammon CJ, Nettles M, Ward SN, Aster RC, Beck SL, Bilek SL, Brudzinski MR, Butler R, DeShon HR, Ekstrom G, Satake K, Sipkin S (2005) The great Sumatra-Andaman earthquake of 26 december 2004. Science 308(5725):1127-1133

2. Ekström G (2007) 4.16 - global seismicity: results from systematic waveform analyses, 1976-2005. In: Schubert G (ed) Treatise on geophysics. Elsevier, Amsterdam, pp 473-481

3. Ammon CJ, Ji C, Thio HK, Robinson D, Ni SD, Hjorleifsdottir V, Kanamori H, Lay T, Das S, Helmberger D, Ichinose G, Polet J, Wald D (2005) Rupture process of the 2004 Sumatra-Andaman earthquake. Science 308:1133-1139

4. Fujii Y, Satake K (2007) Tsunami source model of the 2004 SumatraAndaman earthquake inferred from tide gauge and satellite data. Bull Seism Soc Am 97:S192-S207

5. Kayanne H, Ikeda Y, Echigo T, Shishikura M, Kamataki T, Satake K, Malik JN, Basir SR, Chakrabortty GK, Roy AKG (2007) Coseismic and postseismic creep in the Andaman islands associated with the 2004 Sumatra-Andaman earthquake. Geophys Res Lett 34:L01310

6. Meltzner AJ, Sieh K, Abrams M, Agnew DC, Hudnut KW, Avouac J-P, Natawidjaja DH (2006) Uplift and subsidence associated with the great Aceh-Andaman earthquake of 2004. J Geophys Res Solid Earth 111:B02407

7. Tobita M, Suito H, Imakiire T, Kato M, Fujiwara S, Murakami M (2006) Outline of vertical displacement of the 2004 and 2005 Sumatra earthquakes revealed by satellite radar imagery. Earth Planets Space 58:e1-e4

8. Chlieh M, Avouac J-P, Hjorleifsdottir V, Song T-RA, Ji C, Sieh K, Sladen A, Hebert H, Prawirodirdjo L, Bock Y, Galetzka J (2007) Coseismic slip and afterslip of the great Mw 9.15 Sumatra-Andaman earthquake of 2004. Bull Seism Soc Am 97(1A):S152-S173

9. Titov V, Rabinovich AB, Mofjeld HO, Thomson RE, Gonzalez FI (2005) The global reach of the 26 december 2004 Sumatra tsunami. Science 309(5743):2045-2048

10. Rabinovich AB, Woodworth PL, Titov W (2011) Deep-sea observations and modeling of the 2004 Sumatra tsunami in drake passage. Geophys Res Lett 38(16):L16604

11. Smith WHF, Scharroo R, Titov W, Arcas D, Arbic BK (2005) Satellite altimeters measure tsunami, early model estimates confirmed. Oceanography 18(2):10-12

12. Hanson JF, Reasoner C, Bowman JR (2007) High frequency tsunami signals of the great Indonesian earthquakes of 26 december and 28 march 2005. Bull Seism Soc Am 97:S232-S248

13. Yuan XH, Kind R, Pedersen HA (2005) Seismic monitoring of the Indian ocean tsunami. Geophys Res Lett 32:L15308

14. NOAA (2005) NOAA and the Indian ocean tsunami. http://www.noaanews. noaa.gov/stories2004/s2358.htm. Accessed October 282015

15. International Atomic Energy Agency (2011) Meteorological and hydrological hazards in site evaluation for nuclear installations, vol SSG-18, Specific safety guide. IAEA, Vienna

16. Grecksch G, Kümpel H-J (1997) Statistical analysis of strong-motion accelerograms and its application to earthquake early-warning systems. Geophys J Intl 129(1):113-123

17. Wu Y-M, Teng T-I (2002) A virtual subnetwork approach to earthquake early warning. Bull Seism Soc Am 92(5):2008-2018

18. Kamigaichi O, Saito M, Doi K, Matsumori T, Sy T, Takeda K, Shimoyama T, Nakamura K, Kiyomoto M, Watanabe Y (2009) Earthquake early warning in Japan: warning the general public and future prospects. Seism Res Lett 80(5):717-726

19. Kanamori $H$, Rivera $L$ (2008) Source inversion of $W$ phase: speeding up seismic tsunami warning. Geophys J Intl 175(1):222-238

20. Wang D, Becker NC, Walsh D, Fryer GJ, Weinstein SA, McCreery CS, Sardiña V, Hsu V, Hirshorn BF, Hayes GP, Duputel Z, Rivera L, Kanamori H, Koyanagi KK, Shiro B (2012) Real-time forecasting of the april 11, 2012 Sumatra tsunami. Geophys Res Lett 39(19):L19601

21. Matthews MV, Ellsworth WL, Reasenberg PA (2002) A Brownian model for recurrent earthquakes. Bull Seism Soc Am 92(6):2233-2250

22. Nishenko SP, Buland R (1987) A generic recurrence interval distribution for earthquake forecasting. Bull Seism Soc Am 77:1382-1399

23. Bilham R, Engdahl R, Feldl N, Satyabala SP (2005) Partial and complete rupture of the indo-Andaman plate boundary 1847-2004. Seism Res Lett 76:299-311 
24. Guidoboni E, Ebel JE (2009) Earthquyakes and tsunamis in the past. Cambridge University Press, Cambridge

25. Ishibashi K (2004) Status of historical seismology in Japan. Ann Geophys 47(2/3):339-368

26. Monecke K, Finger W, Klarer D, Kongko W, McAdoo BG, Moore AL, Sudrajat SU (2008) A 1,000-year sediment record of tsunami recurrence in northern Sumatra. Nature 455(7217):1232-1234

27. Fujino S, Naruse H, Matsumoto D, Jarupongsakul T, Sphawajruksakul A, Sakakura N (2009) Stratigraphic evidence for pre-2004 tsunamis in southwestern Thailand. Mar Geol 262:25-28

28. Jankaew K, Atwater BF, Sawai Y, Choowong M, Charoentitirat T, Martin ME, Prendergast A (2008) Medieval forewarning of the 2004 Indian ocean tsunami in Thailand. Nature 455(7217):1228-1231

29. Prendergast AL, Cupper ML, Jankaew K, Sawai Y (2012) Indian ocean tsunami recurrence from optical dating of tsunami sand sheets in Thailand. Mar Geol 295-298:20-27

30. Malik JN, Shishikura M, Echigo T, Ikeda Y, Satake K, Kayanne H, Sawai Y, Murty CVR, Dikshit O (2011) Geologic evidence for two pre-2004 earthquakes during recent centuries near port Blair, south Andaman island, India. Geology 39(6):559-562

31. Rajendran CP, Rajendran K, Andrade V, Srinivasalu S (2013) Ages and relative sizes of pre-2004 tsunamis in the Bay of Bengal inferred from geologic evidence in the Andaman and Nicobar islands. J Geophys Res Solid Earth 117:1345-1362

32. Rajendran $C P$, Rejendran $K$, Machado T, Satyamurthy T, Aravazhi P, Jaiswal M (2006) Evidence of ancient sea surges at the mamallapuram coast of India and implications for previous Indian ocean tsunami events. Curr Sci 91(9):1242-1247

33. Uyeda S, Kanamori H (1979) Back-arc opening and the mode of subduction. J Geophys Res Solid Earth 84(B3):1049-1061

34. Ruff L, Kanamori H (1980) Seismicity and the subduction process. Phys Earth Planet Inter 23:240-252

35. Stein S, Okal E (2007) Ultralong period seismic study of the december 2004 Indian ocean earthquake and implications for regional tectonics and the subduction process. Bull Seism Soc Am 97:S279-S295

36. McCaffrey R (2008) Global frequency of magnitude 9 earthquakes. Geology 36(3):263-266

37. Kanamori H (1977) The energy release in great earthquakes. J Geophys Res Solid Earth 82:2981-2987

38. Matsuzawa T (2014) The largest EarthquakesWe should prepare for. J Disaster Res 9(3):248-251

39. Satake K, Atwater BF (2007) Long-term perspectives on giant earthquakes and tsunamis at subduction zones. Annu Rev Earth Planet Sci 35:349-374

40. Cisternas M, Atwater BF, Torrejon F, Sawai Y, Machuca G, Lagos M, Eipert A Youlton C, Salgado I, Kamataki T, Shishikura M, Rajendran CP, Malik JK, Rizal Y, Husni M (2005) Predecessors of the giant 1960 Chile earthquake. Nature 437(7057):404-407

41. Okada Y (1985) Surface deformation due to shear and tensile faults in a half-space. Bull Seism Soc Am 75:1135-1154

42. Tanioka Y, Satake K (1996) Tsunami generation by horizontal displacement of ocean bottom. Geophys Res Lett 23(8):861-864

43. Satake K, Fujii Y, Harada T, Namegaya Y (2013) Time and space distribution of coseismic slip of the 2011 Tohoku earthquake as inferred from tsunami waveform data. Bull Seism Soc Am 103(2B):1473-1492

44. Kanamori H (1972) Mechanism of tsunami earthquakes. Phys Earth Planet Inter 6:246-259

45. Satake K, Tanioka Y (1999) Sources of tsunami and tsunamigenic earthquakes in subduction zones. Pure Appl Geophys 154(3-4):467-483

46. Tsuji Y, Satake K, Ishibe T, Harada T, Nishiyama A, Kusumoto S (2014) Tsunami heights along the pacific coast of northern Honshu recorded from the 2011 Tohoku and previous great earthquakes. Pure Appl Geophys 1-33, doi:10.1007/s00024-014-0779-x

47. Satake K (1994) Mechanism of the 1992 Nicaragua tsunami earthquake. Geophys Res Lett 21(23):2519-2522

48. Satake K, Nishimura Y, Putra PS, Gusman AR, Sunendar H, Fujii Y, Tanioka Y, Latief H, Yulianto E (2013) Tsunami source of the 2010 mentawai, Indonesia earthquake inferred from tsunami field survey and waveform modeling. Pure Appl Geophys 170:1567-1582

49. Foster JH, Brooks BA, Wang D, Carter GS, Merrifield MA (2012) Improving tsunami warning using commercial ships. Geophys Res Lett 39(9):L09603
50. González Fl, Bernard EN, Meinig C, Eble MC, Mofjeld HO, Stalin S (2005) The NTHMP tsunameter network. Nat Hazards 35(1):25-39

51. Mungov G, Eblé M, Bouchard R (2013) DART ${ }^{\oplus}$ tsunameter retrospective and real-time data: a reflection on 10 years of processing in support of tsunami research and operations. Pure Appl Geophys 170(9-10):1369-1384

52. Nakano M, Nakamura T, Kamiya S, Ohori M, Kaneda Y (2013) Intensive seismic activity around the nankai trough revealed by DONET ocean-floor seismic observations. Earth Planets Space 65:5-15

53. Uehira K, Kanazawa T, Noguchi S, Aoi S, Kunugi T, Matsumoto T, Okada Y, Sekiguchi S, Shiomi K, Yamada T (2012) Ocean bottom seismic and tsunami network along the Japan trench. AGU Fall Meeting Abstracts:OS41C-1736 presented at 2012 Fall Meeting, AGU, San Francisco, California, 3-7 December

54. Satake K (1995) Linear and nonlinear computations of the 1992 Nicaragua earthquake tsunami. Pure Appl Geophys 144(3-4):455-470

55. Imamura F (2009) Tsunami modeling: calculating inundation and hazard maps. In: Bernard EN, Robinson AR (eds) Tsunamis, vol 15, The Sea, volume 15. Harvard University Press, Cambridge, pp 321-332

56. Satake K (1989) Inversion of tsunami waveforms for the estimation of heterogeneous fault motion of large submarine earthquakes - the 1968 tokachi-Oki and 1983 Japan Sea earthquakes. J Geophys Res Solid Earth 94(B5):5627-5636

57. Kamigaichi O (2009) Tsunami forecasting and warning. In: Meyers RA (ed) Encyclopedia of complexity and systems science. Springer, New York, pp 9592-9613

58. Tatehata H (1997) The new tsunami warning system of the Japan meteorological agency. In: Hebenstreit G (ed) Perspectives on tsunami hazards reduction. Kluwer Academic Publishers, Dordrecht, pp 175-188

59. Tang L, Titov W, Chamberlin CD (2009) Development, testing, and applications of site-specific tsunami inundation models for real-time forecasting. J Geophys Res Oceans 114(C12):C12025

60. Tsushima H, Hino R, Fujimoto H, Tanioka Y, Imamura F (2009) Near-field tsunami forecasting from cabled ocean bottom pressure data. J Geophys Res Solid Earth 114(B6):B06309

61. Tsushima H, Hino R, Tanioka Y, Imamura F, Fujimoto H (2012) Tsunami waveform inversion incorporating permanent seafloor deformation and its application to tsunami forecasting. J Geophys Res Solid Earth 117(B3):B03311

62. Yasuda T, Mase H (2013) Real-time tsunami prediction by inversion method using offshore observed GPS buoy data: nankaido. J Waterway Port Coastal Ocean Engin 139(3):221-231

63. Tsushima H, Hino R, Ohta Y, linuma T, Miura S (2014) TFISH/RAPiD: rapid improvement of near-field tsunami forecasting based on offshore tsunami data by incorporating onshore GNSS data. Geophys Res Lett 41(10):L059863

64. Gusman AR, Tanioka Y, Maclnnes BT, Tsushima H (2014) A methodology for near-field tsunami inundation forecasting: application to the 2011 Tohoku tsunami. J Geophys Res Solid Earth 2014JB010958, doi:10.1002/2014JB010958

65. Watada S, Kusumoto S, Satake K (2014) Traveltime delay and initial phase reversal of distant tsunamis coupled with the self-gravitating elastic earth. J Geophys Res Solid Earth 119(5):4287-4310

66. Ozawa S, Nishimura T, Suito H, Kobayashi T, Tobita M, Imakiire T (2011) Coseismic and postseismic slip of the 2011 magnitude-9 tohoku-oki earthquake. Nature 475(7356):373-376

67. Fujiwara T, Kodaira S, No T, Kaiho Y, Takahashi N, Kaneda Y (2011) The 2011 tohoku-oki earthquake: displacement reaching the trench axis. Science 334(6060):1240

68. Kido M, Osada Y, Fujimoto H, Hino R, Ito Y (2011) Trench-normal variation in observed seafloor displacements associated with the 2011 tohoku-oki earthquake. Geophys Res Lett 38:L24303

69. Sato M, Ishikawa T, Ujihara N, Yoshida S, Fujita M, Mochizuki M, Asada A (2011) Displacement above the hypocenter of the 2011 tohoku-oki earthquake. Science 332(6036):1395

70. Tanioka Y, Satake K (1996) Fault parameters of the 1896 sanriku tsunami earthquake estimated from tsunami numerical modeling. Geophys Res Lett 23(13):1549-1552

71. Sawai Y, Namegaya Y, Okamura Y, Satake K, Shishikura M (2012) Challenges of anticipating the 2011 Tohoku earthquake and tsunami using coastal geology. Geophys Res Lett 39, L21309

72. Fujii Y, Satake K, Sakai S, Shinohara M, Kanazawa T (2011) Tsunami source of the 2011 off the pacific coast of Tohoku earthquake. Earth Planets Space 63(7):815-820 
73. Ozaki T (2011) Outline of the 2011 off the pacific coast of Tohoku earthquake (Mw 9.0) -tsunami warnings/advisories and observations-. Earth Planets Space 63:827-830

74. Earthquake Research Committee (2009) Long-term evaluation of earthquakes from sanriku-oki to boso-oki. Headquarters for Earthquake Research Promotion, Tokyo

75. Satake K, Fujii Y (2014) Review: source models of the 2011 Tohoku earthquake and long-term forecast of large earthquakes. J Disaster Res 9(3):272-280

76. Minoura K, Nakaya S (1991) Traces of tsunami preserved in inter-tidal lacustrine and marsh deposits - some examples from northeast Japan. J Geology 99(2):265-287

77. Minoura K, Imamura F, Sugawara D, Kono Y, Iwashita T (2001) The 869 jogan tsunami deposit and recurrence interval of large-scale tsunami on the pacific coast of norheast Japan. J Natural Disaster Sci 23:83-88

78. Goto K, Fujima K, Sugawara D, Fujino S, Imai K, Tsudaka R, Abe T, Haraguchi $T$ (2012) Field measurements and numerical modeling for the run-up heights and inundation distances of the 2011 tohoku-oki tsunami at Sendai plain. Earth Planets Space 64:1247-1257

79. Nakajima H, Koarai M (2011) Assessment of tsunami flood situation from the great east Japan earthquake. Bull Geospatial Info Authority Japan 59:55-66

80. Stohl A, Seibert P, Wotawa G, Arnold D, Burkhart JF, Eckhardt S, Tapia C, Vargas A, Yasunari TJ (2012) Xenon-133 and caesium-137 releases into the atmosphere from the Fukushima Dai-Ichi nuclear power plant: determination of the source term, atmospheric dispersion, and deposition. Atmos Chem Phys 12:2313-2343

81. Miyazawa Y, Masumoto Y, Varlamov SM, Miyama T, Takigawa M, Honda M, Saino T (2013) Inverse estimation of source parameters of oceanic radioactivity dispersion models associated with the Fukushima accident. Biogeosciences 10(4):2349-2363

82. Kato H, Onda Y, Gomi T (2012) Interception of the Fukushima reactor accident-derived137Cs, 134Cs and 1311 by coniferous forest canopies. Geophys Res Lett 39(20):L20403

83. Allen SCR, Greenslade DJM (2008) Developing tsunami warnings from numerical model output. Nat Hazards 46(1):35-52

84. Kumar TS, Nayak S, Kumar P, Yadav RBS, Kumar A, Sunanda MV, Devi EU, Shenoi SSC (2012) Performance of the tsunami forecast system for the Indian ocean. Curr Sci 102(1):110-114

85. Munch U, Rudloff A, Lauterjung J (2011) Postface "the GITEWS project results, summary and outlook". Nat Hazards Earth Syst Sci 11(3):765-769

86. Geist E, Parsons T (2006) Probabilistic analysis of tsunami hazards. Nat Hazards 37:277-314

87. González Fl, Geist EL, Jaffe B, Kânoğlu U, Mofjeld H, Synolakis CE, Titov W, Arcas D, Bellomo D, Carlton D, Horning T, Johnson J, Newman J, Parsons T, Peters R, Peterson C, Priest G, Venturato A, Weber J, Wong F, Yalciner A (2009) Probabilistic tsunami hazard assessment at seaside, Oregon, for near- and far-field seismic sources. J Geophys Res Oceans 114(C11):C11023

88. Annaka T, Satake K, Sakakiyama T, Yanagisawa K, Shuto N (2007) Logic-tree approach for probabilistic tsunami hazard analysis and its applications to the Japanese coasts. Pure Appl Geophys 164(2-3):577-592

89. Sakai T, Takeda T, Soraoka H, Yanagisawa K, Annaka T (2006) Development of a probabilistic tsunami hazard analysis in Japan. In: Proceedings of ICONE 14, international conference on nuclear engineering. ASME (American Society of Mechanical Engineers), Miami, Florida, USA, pp 1-7

90. Kodama S (2013) Tsunami-tendenko and morality in disasters. J Medical Ethics doi:10.1136/medethics-2012-100813

91. Yamori K (2013) Revisiting the concept of tsunami tendenko: tsunami evacuation behavior in the great east Japan earthquake. J Disaster Res 8:115-116

doi:10.1186/s40562-014-0015-7

Cite this article as: Satake: Advances in earthquake and tsunami sciences and disaster risk reduction since the 2004 Indian ocean tsunami. Geoscience Letters 2014 1:15.

\section{Submit your manuscript to a SpringerOpen ${ }^{\odot}$ journal and benefit from:}

- Convenient online submission

- Rigorous peer review

- Immediate publication on acceptance

- Open access: articles freely available online

- High visibility within the field

- Retaining the copyright to your article

Submit your next manuscript at $\gg$ springeropen.com 